\title{
Changes in bacterial activity and community structure in response to dissolved organic matter in the Hudson River, New York
}

\author{
David L. Kirchman ${ }^{1, *}$, Ana I. Dittel ${ }^{1}$, Stuart E. G. Findlay ${ }^{2}$, David Fischer ${ }^{2}$ \\ ${ }^{1}$ College of Marine Studies, University of Delaware, Lewes, Delaware 19958, USA \\ ${ }^{2}$ Institute of Ecosystem Studies, Millbrook, New York 12545, USA
}

\begin{abstract}
This study examined the effect of dissolved organic matter (DOM) on ectoenzymatic activity, bacterial growth and community structure in the Hudson River. Our main approach was to mix bacterial communities and water from various locations in the Hudson River and its tributaries, and then to monitor bacterial activity and community structure determined by fluorescence in situ hybridization with oligonucleotide probes. The locations differed significantly in DOM composition and concentrations, ectoenzyme activity and bacterial community structure. We found that water source and, to a lesser extent, source of the inoculum significantly affected nearly all aspects of bacterial activity and community structure. A common inoculum grown in different waters often led to as much as a 2 -fold difference in enzyme activities. When 2 different bacterial communities were inoculated in the same water, community structure and the activity of some ectoenzymes remained different after several days. Other data also pointed to a dependence of ectoenzyme activity on community structure. Activity of several ectoenzymes covaried with the relative abundances of the 4 bacterial groups we examined (alpha-, beta- and gamma-proteobacteria, and Cytophaga-like bacteria); the highest correlation was between beta-proteobacteria and phosphatase activity. In multi-variate regression analyses, community structure explained a significant amount of the variation in rates of all ectoenzymes except 2 proteases. The abundance of Cytophaga-like bacteria was the dominant variable in the regression models for the activity of 3 ectoenzymes. These data suggest that DOM can affect the relative abundance of the major heterotrophic bacterial groups, and that the relative abundance of these groups could have an impact on DOM hydrolysis.
\end{abstract}

KEY WORDS: Bacteria - Community structure - Bacterial production · Extracellular enzymes · Hudson River · Fluorescence in situ hybridization · Dissolved organic carbon

\section{INTRODUCTION}

Biotic mineralization of dissolved organic material (DOM) in aquatic ecosystems is carried out by a diverse community of heterotrophic microbes, potentially consisting of representatives from over 50 divisions (or phyla) of bacteria and Archaea (Rappé \& Giovannoni 2003). In aerobic water columns of many aquatic ecosystems, the heterotrophic assemblage is dominated by only a few bacterial groups from 2 of these divisions (Giovannoni \& Rappé 2000, Kirchman 2002); Archaea appear to be abundant in the deep ocean, but not in surface waters (Karner et al. 2001).
The abundant heterotrophic bacterial groups in surface waters include 3 subdivisions of Proteobacteria (alpha-, beta-, and gamma-proteobacteria) and a subgroup of the Bacteroidetes, often referred to as Cytophaga-Flavobacterium or Cytophaga-like bacteria. Actinobacteria can be another abundant group in freshwaters (Glöckner et al. 2000), although these waters are often dominated by beta-proteobacteria (Glöckner et al. 1999). Alpha-proteobacteria, including the SAR11 clade (Morris et al. 2002), are abundant in the oceans (Glöckner et al. 1999) whereas Cytophagalike bacteria can be abundant in both freshwater and marine systems (Kirchman 2002). 
The abundances of these bacterial groups are probably affected by several factors, including the composition and concentration of DOM. These and other DOM parameters often control community-level rates of bacterial growth and biomass production, and there is evidence of DOM affecting the structure of natural bacterial communities (Rossello-Mora et al. 1999, van Hannen et al. 1999, Eilers et al. 2000a, Covert \& Moran 2001, Fandino et al. 2001, Muylaert et al. 2002, Findlay et al. 2003). That DOM affects the abundance of individual 'species' or ribotypes (e.g. van Hannen et al. 1999, Fandino et al. 2001, Muylaert et al. 2002) would not be surprising, because bacteria in pure cultures are well known to differ in their capacity to use various DOM components (Martinez et al. 1996). What is less clear is the impact of DOM on the abundance of major phylogenetic groups such as the subdivisions of Proteobacteria and Cytophaga-like bacteria. Variation in DOM may affect the abundance of these phylogenetic groups if there are systematic differences in how these groups use or respond to DOM or if these groups are consistently dominated by a few species that differ in DOM utilization Cottrell \& Kirchman (2000) found differences in DOM use among subdivisions of Proteobacteria and Cytophaga-like bacteria, supporting the common generalization that Cytophaga-like bacteria are adept at using biopolymers and high molecular weight (HMW) DOM (Kirchman 2002). Davey et al. (2001) noted that high Cytophaga-like bacterial abundance and proteolytic activity co-occurred in surface waters of the northeast Atlantic Ocean. However, it is still unclear whether generalizations about DOM use at this phylogenetic level will prove useful, because each of these groups contains several subgroups and ribotypes (Giovannoni \& Rappé 2000) that probably vary greatly over time and space.

An important step in DOM mineralization which community structure may affect is the hydrolysis of HMW DOM by cell-associated extracellular enzymes (ectoenzymes). Although not necessarily a rate-limiting step in DOM degradation (Arnosti 2003), it is often the first step because the molecular size of labile DOM is frequently large enough (Amon \& Benner 1994, Amon \& Benner 1996) to require extracellular hydrolysis before transport and ultimate mineralization. Previous work with pure cultures demonstrated that ectoenzyme activity varies greatly among bacterial species, and that no single species expresses all ectoenzymes with high activity (Martinez et al. 1996), and so variation in bacterial community may be linked with variation in enzymatic activity. Little is known about the ectoenzyme activity of uncultured bacterial groups, except for the possible special role of Cytophaga-like bacteria in HMW DOM hydrolysis (see above). It is unclear if all bacterial communities are equally capable of expressing all enzymes necessary for hydrolyzing the range of HMW DOM components found in natural aquatic ecosystems, or if a new community must develop before new DOM components are hydrolyzed and ultimately mineralized.

Lakes and rivers may be ideal systems to explore relationships between community structure and DOM properties, since the amount and composition of DOM can vary greatly in these aquatic systems (Cotner et al. 2000, Mulholland et al. 2001, Cole et al. 2002). In the Hudson River, for example, concentrations of dissolved organic carbon (DOC) vary spatially by nearly 2-fold, and several direct and indirect indices suggest even greater variation in DOM composition (Findlay et al. 1998). This variation is caused by input of DOM from both plankton and terrestrial sources. Plankton-derived DOM is enriched in protein and labile polysaccharides, whereas terrestrial DOM contains humic material and structural polysaccharides, such as cellulose and lignin, which are relatively resistant to mineralization by microbial processes (Benner 2002, 2003). DOM in rivers, which is often dominated by terrestrial organic material, appears to be relatively less labile than DOM in marine systems, which is mostly from planktonic sources. In long-term bioassays, ca. $12 \%$ of DOC from rivers is consumed on average, only half as much as the average fraction (26\%) consumed in bioassays of marine DOC (del Giorgio \& Davis 2003).

We examined relationships among ectoenzyme activity, bacterial growth, and bacterial community structure in the Hudson River and its tributaries. Our main approach was to mix bacterial communities and water from various locations within the Hudson River system and then to monitor bacterial biomass production, ectoenzyme activity, and community structure. The data from these experiments help us explore bidirectional controls: the influence of DOM on bacterial composition and activity, and the role of bacterial community structure in controlling DOM degradation. We found that both ectoenzymatic activity and bacterial community structure changed in response to DOM composition and concentrations and that the activities of several ectoenzymes were associated with changes in microbial community structure.

\section{MATERIALS AND METHODS}

The water and microbial assemblages used in these experiments were from locations spanning the tidal Hudson River, which extends for $240 \mathrm{~km}$ from north of Albany (Peebles Island State Park, above the dam, but referred to here as 'Albany') to New York City (Dykeman Street RM10 in Manhattan) (Fig. 1). Water was taken from these locations and transported to the laboratory, where processing began within $4 \mathrm{~h}$. In addition to the 


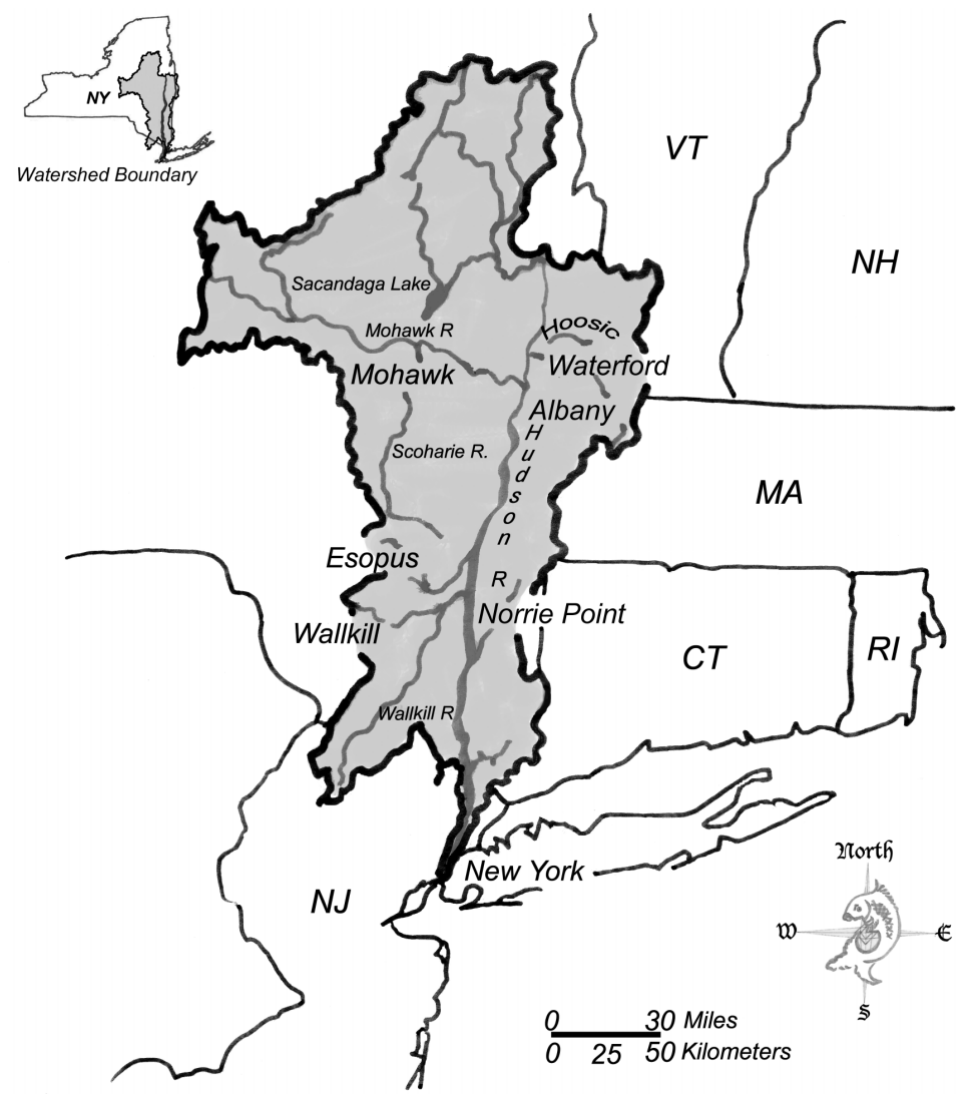

Fig. 1. Hudson River, illustrating the sources of water and inocula for the upstream-downstream switch experiments (Albany and New York City) and the tributary experiments (Mohawk, Esopus Creek, Wallkill Creek, Waterford). Water from Norrie Point was the inoculum for the tributary experiment

experiments (see below), ambient water (see 'Results') was analyzed to characterize the sample locations.

Dissolved organic carbon in ambient waters and from the experimental flasks was measured with a Shimadzu 5050 TOC Analyzer. Fluorescence characteristics of ambient waters were measured with a Perkin Elmer spectrofluorometer. Concentrations of dissolved inorganic nitrogen (DIN) and soluble reactive phosphorus (SRP) in ambient waters were measured by standard automated wet chemistry.

Bacterial growth experiments. Two types of growth experiments were conducted. One set used water and microbial assemblages (the inoculum) from 2 endmembers of the Hudson River, Albany and New York City ('switch experiments'). In brief, $900 \mathrm{ml}$ of $0.22 \mu \mathrm{m}$ filtered water (mixed esters of cellulose, Millipore GS) from each site was inoculated with $100 \mathrm{ml}$ of an unfiltered inoculum derived from either the same location or the opposite endmember. Each treatment had 3 replicates. The experiments were then subsampled daily for ${ }^{3} \mathrm{H}$-leucine incorporation (see below) to track growth, and the experiment was terminated when rates were relatively constant.

Another type of bacterial growth experiment ('tributary' experiment) consisted of adding one inoculum to water from 3 tributaries of the Hudson River and from a 4th location, the upper Hudson River near Waterford, above the tidal portion. The inoculum was from Norrie Point (Fig. 1), which is near the longitudinal mid-point of the main stem of the tidal Hudson. The 3 tributaries were Mohawk River, Esopus Creek and Wallkill River. As with the switch experiment, an unfiltered inoculum $(100 \mathrm{ml})$ was added to $0.22 \mu \mathrm{m}$-filtered water $(900 \mathrm{ml})$. Each treatment had 3 replicates, which were subsampled over time as described above.

Bacterial growth was assayed at 5 time points $(0$, $24,48,54$ and $72 \mathrm{~h}$ ) as the rate of incorporation of ${ }^{3}$ H-leucine (Smith \& Azam 1992, Kirchman 2001). At the end of the experiment, ectoenzyme activity, bacterial community structure (see below), and the rate of incorporation of ${ }^{3} \mathrm{H}$-thymidine into DNA was measured using the procedure routinely used for field samples in the Hudson River (Findlay et al. 1991).

Ectoenzyme activity. The activity of various ectoenzymes was measured both in the experiments and at the locations in the Hudson system where we collected water and microbes for the experiments. The procedure followed that already described elsewhere (Findlay et al. 1998). In brief, ectoenzyme activity was assayed by observing the release of fluorescent methylumbelliferone (MUF) from MUF-linked analogues. The following substrates were used for the indicated enzyme ('substrate for enzyme'): 4-MUF-acetate for esterase; 4MUF-phosphate for phosphatase; L-leucine 7-amido-4methyl-coumarin for aminopeptidase; 4-MUF-alphaglucoside for alpha-glucosidase; 4-MUF-beta-glucoside for beta-glucosidase; 4-MUF-beta-xyloside for xlyase; 4MUF-beta-N-acetylglucosaminide for beta-N-acetylglucosaminidase; 4-MUF-4-guanidinobenzoate for trypsin. Enzyme activity was measured at a single concentration $(400 \mu \mathrm{M}$, except for MUF-acetate which was added at $100 \mu \mathrm{M})$. These concentrations resulted in maximal enzyme rates or were at the solubility limit of the substrate (Findlay et al. 1998). Fluorescence was monitored over 1 to $4 \mathrm{~h}$ in a 96-well microtiter plate spectrofluorometer (Perkin-Elmer LS50B) and the rate was calculated from the linear part of the fluorescence versus time relationship. Fluorescence quenching was corrected by addition of internal standards (addition of known amounts of MUF to actual samples) and fluorescent units were converted to molar rates with a standard curve.

Fluorescence in situ hybridization (FISH). Bacterial community structure was examined by FISH with oligonucleotide probes (Amann et al. 1995). Water for this analysis was preserved in $2 \%$ formaldehyde and 
frozen $\left(-20^{\circ} \mathrm{C}\right)$ until filtration through $0.2 \mu \mathrm{m}$ polycarbonate filters was possible. The number of cells detectable by FISH after this preservation appears to be similar to that in samples preserved in paraformaldehyde without freezing (Cottrell \& Kirchman unpubl. data).

The relative abundance of major phylogenetic groups was determined using CY3-labeled (MWG Biotech) Probe Eub338 for bacteria (Amann et al. 1990), Alf968 for alpha-proteobacteria (Glöckner et al. 1999), Bet42a for beta-proteobacteria (Manz et al. 1992), Gam42a for gamma-proteobacteria, CF319a for the Cytophaga-like bacterial group (Manz et al. 1996) and a negative control probe for non-specific binding (Karner \& Fuhrman 1997). Samples were probed for 18 to $20 \mathrm{~h}$ at $42^{\circ} \mathrm{C}$. The hybridization solution contained $0.9 \mathrm{M} \mathrm{NaCl}, 20 \mathrm{mM}$ Tris-HCl (pH 7.4), $0.01 \%$ sodium dodecyl sulfate, and the appropriate concentration of formamide (Zarda et al. 1997, Eilers et al. 2000b). After hybridization, the sample was transferred to a wash solution containing $20 \mathrm{mM}$ Tris- $\mathrm{HCl}(\mathrm{pH} 7.4), 5 \mathrm{mM}$ EDTA, $0.01 \%$ sodium dodecyl sulfate, and a concentration of $\mathrm{NaCl}$ appropriate for the probe (Zarda et al. 1997, Eilers et al. 2000b). After staining with DAPI, the sample was mounted with Vectashield and Citifluor (1:4) and examined with a semi-automated image analysis system coupled to an Olympus epifluorescence microscope (Cottrell \& Kirchman 2003).

Statistical analysis. The data were analyzed by standard ANOVA and regression techniques. The FISH data, which were expressed as a percentage of total prokaryotes (DAPI-positive cells), were arcsin transformed before analysis. A principal components analysis (PCA) was used to simplify the 8 enzyme activities or the abundance of 4 bacterial groups into 2 new linear variables that encompassed most of the variability in the original data. The PCA uses the correlation among variables rather than absolute rates, so all variables have equal weight in the analysis.

\section{RESULTS}

\section{Ambient DOM and bacterial communities}

DOM characteristics and the bacterial communities differed greatly among the sampling sites examined by this study. There was a 2-fold difference in bulk DOC concentration among the tributaries and a ca. $25 \%$ difference between New York City (NYC) and Albany, which served as sites for the switch experiments (Fig. 1). These concentration differences parallel previously observed gradients in DOC in the Hudson River (Findlay et al. 1996). DOC composition, as revealed by in vivo fluorescence (McKnight et al. 2001), also varied among sites; the lowest ratios of fluorescence to DOC were in the Wallkill (fluorescence $=1.82 \pm 0.03$ [SD] and $\mathrm{DOC}=6.2 \mathrm{mg} \mathrm{C}^{-1}$ ) and the highest in NYC water (fluorescence $=2.0 \pm 0.07$ and $\mathrm{DOC}=3 \mathrm{mgC} \mathrm{l}^{-1}$ ), implying less of a contribution of humic material in the latter. Inorganic nutrient concentrations also varied spatially, with much higher DIN and SRP concentrations in NYC $\left(1.03 \pm 0.2 \mathrm{mg} \mathrm{N} \mathrm{l}^{-1} ; 0.13 \pm 0.05 \mathrm{mg} \mathrm{P} \mathrm{l}^{-1}\right)$ than near Albany $\left(0.31 \pm 0.17 \mathrm{mg} \mathrm{N}^{-1} ; 0.008 \pm 0.0003 \mathrm{mg} \mathrm{P}^{-1}\right)$. Tributaries were more similar in DIN (0.4 to $0.6 \mathrm{mg} \mathrm{N}$ $\left.\mathrm{l}^{-1}\right)$ but had larger differences in SRP $(0.02 \pm 0.01 \mathrm{mg} \mathrm{P}$ $\mathrm{l}^{-1}$ for Mohawk; $0.04 \pm 0.04 \mathrm{mg} \mathrm{P}^{-1}$ for Waterford; $0.006 \pm 0.006 \mathrm{mg} \mathrm{P} \mathrm{l}^{-1}$ in Esopus; $0.062 \pm 0.003 \mathrm{mg} \mathrm{P} \mathrm{l}^{-1}$ for Wallkill).

The relative amount of labile DOM differed among some of the locations we examined. Labile DOM was estimated from the decrease in DOC concentrations in experiments where we added a bacterial inoculum to water from the various locations (see below). Absolute loss of DOC (change in $\mathrm{mgC}^{-1}$ ) over the experimental period did not differ among water sources, but the percent loss was significantly higher $\left(F_{5,40}=4.58 ; \mathrm{p}=\right.$ 0.002) for the Albany and NYC waters than for 3 (Waterford, Mohawk and Wallkill) of the 4 tributaries we examined. The relative amount of labile DOC from Albany and NYC was similar; 25 to $27 \%$ of the initial DOC was depleted over the 3 to $4 \mathrm{~d}$ duration of the experiments compared with 9.6 to $14.2 \%$ for the 3 tributaries. The labile DOM fraction at Albany and NYC was not significantly different from that of the 4 th tributary, Esopus Creek (18.4\%).

Bacterial community structure, ectoenzyme activity and biomass production (leucine incorporation) were examined in unmanipulated bulk water at 3 locations in the main stem of the Hudson River and in 3 tributaries in late summer or fall of 1999, 2000, and 2001. Nearly all variables differed significantly, due to both location and time $(\mathrm{p}<0.05$; ANOVA). Ectoenzyme activity varied from 2 -fold (N-acetylglucosaminidase) to nearly 6-fold (aminopeptidase) among the Hudson River locations and tributaries (Table 1). Concomitant with this variation, we observed differences in community structure as revealed by FISH.

The fraction of cells detectable by FISH (Eub338-positive cells) varied nearly 2 -fold, due to location with the Albany and Waterford sites having the lowest (40 $\pm 12 \%$ ) and highest ( $76 \pm 7 \%$ ) percentage, respectively. Of the 4 bacterial groups we examined, the most abundant group was either 1 of 2 proteobacterial subdivisions (alpha- or beta-proteobacteria) or the Cytophaga-like bacteria; the least abundant group was always the gamma-proteobacteria (Fig. 2), which usually accounted for $<10 \%$ of total abundance. Alpha-proteobacteria were quite abundant ( $45 \%$ of total) and beta-proteobacteria relatively rare (ca. $5 \%$ ) in the Esopus tributary, which is surprising 
Table 1. Summary of in situ enzyme activities in the Hudson River system. Means $( \pm \mathrm{SE})$ of rates measured in triplicates on 3 (New York City [NYC] and Albany) or 2 dates (all other sites). The 6 locations are arranged from the northernmost station on the left. Units for alpha-glucosidase, beta-glucosidase, $\mathrm{N}$-acetylglucosamindase and xylosidase are pmol $\mathrm{l}^{-1} \mathrm{~h}^{-1}$, whereas the units for the remaining enzymes are $n m o l \mathrm{l}^{-1} \mathrm{~h}^{-1}$

\begin{tabular}{|c|c|c|c|c|c|c|}
\hline \multirow[t]{2}{*}{ Enzyme } & \multicolumn{6}{|c|}{ Enzyme activity (pmol or $\mathrm{nmol} \mathrm{l}^{-1} \mathrm{~h}^{-1}$ ) } \\
\hline & Waterford & Mohawk & Albany & Esopus & Wallkill & NYC \\
\hline Alpha-glucosidase & $3.66 \pm 1.34$ & $6.35 \pm 1.84$ & $9.17 \pm 0.76$ & $7.64 \pm 1.11$ & $11.19 \pm 2.12$ & $8.08 \pm 1.51$ \\
\hline Beta-glucosidase & $13.4 \pm 3.0$ & $17.2 \pm 4.1$ & $29.5 \pm 7.8$ & $21.3 \pm 3.5$ & $35.7 \pm 9.1$ & $18.8 \pm 4.1$ \\
\hline N-acetylglucosamindase & $12.0 \pm 3.1$ & $24.5 \pm 7.9$ & $19.2 \pm 5.0$ & $17.6 \pm 3.6$ & $24.4 \pm 5.3$ & $14.1 \pm 1.5$ \\
\hline Xylosidase & $5.83 \pm 1.61$ & $6.99 \pm 1.82$ & $8.26 \pm 1.47$ & $10.22 \pm 0.56$ & $3.7 \pm 1.65$ & $6.7 \pm 0.87$ \\
\hline Phosphatase & $0.148 \pm 0.003$ & $0.166 \pm 0.025$ & $0.175 \pm 0.005$ & $0.170 \pm 0.005$ & $0.389 \pm 0.130$ & $0.153 \pm 0.011$ \\
\hline Aminopeptidase & $0.215 \pm 0.020$ & $0.675 \pm 0.260$ & $0.148 \pm 0.020$ & $0.246 \pm 0.066$ & $0.683 \pm 0.191$ & $0.115 \pm 0.010$ \\
\hline Esterase & $2.24 \pm 0.31$ & $4.06 \pm 0.17$ & $4.27 \pm 0.54$ & $3.70 \pm 0.58$ & $4.45 \pm 0.15$ & $5.34 \pm 1.12$ \\
\hline Trypsin & $1.99 \pm 0.18$ & $3.82 \pm 0.35$ & $3.88 \pm 0.87$ & $2.53 \pm 0.13$ & $3.49 \pm 0.30$ & $1.09 \pm 0.30$ \\
\hline
\end{tabular}

since beta-proteobacteria often dominate freshwater systems (Glöckner et al. 1999). At the other extreme, beta-proteobacteria dominated the Wallkill tributary (on average $35 \%$ of total abundance), whereas alpha-proteobacteria were only ca. $10 \%$ of total prokaryotic abundance. In the entire data set, there was no significant correlation between alpha- and beta-proteobacterial abundances (see below).

\section{Upstream-downstream switch experiments}

We hypothesized that some of the differences in ambient ectoenzyme activity and community structure observed in the Hudson River system were due to differences in DOM composition. To explore this hypothesis, we conducted 'switch' experiments in which a bacterial inoculum from one site was added to

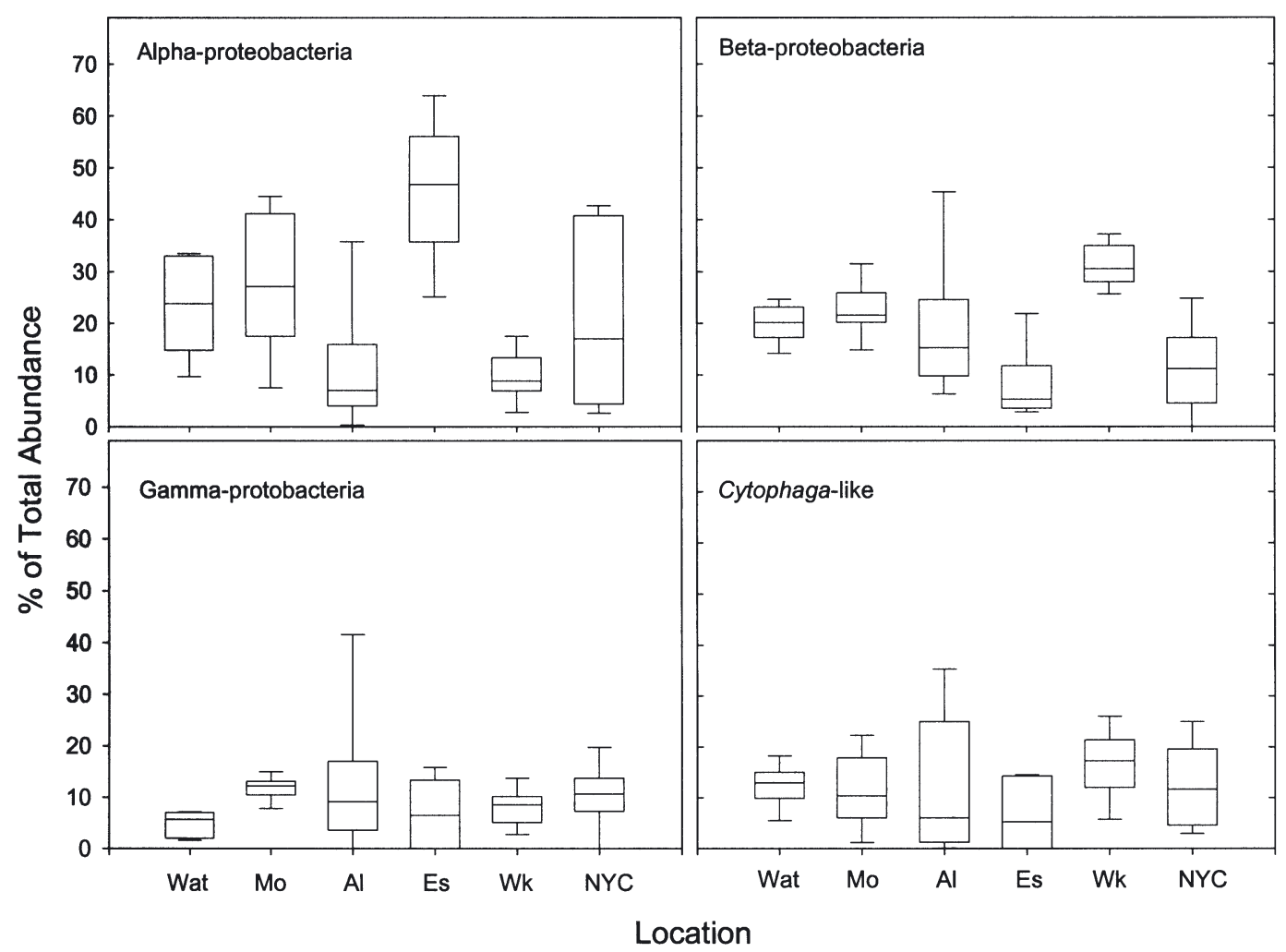

Fig. 2. Box and whisker plots of bacterial community structure (fluorescence in situ hybridization; FISH) at the locations used in the experiments (see Fig. 1). The data for Albany and New York are averaged over $3 \mathrm{yr}$, whereas the data presented for the other sites are from a single date (October 2000) with the statistics reflecting the within-sample variation of the FISH method. Wat $=$ Waterford $; \mathrm{Mo}=$ Mohawk; $\mathrm{Al}=$ Albany; Es = Esopus; $\mathrm{Wk}=$ Wallkill $; \mathrm{NYC}=$ New York City 
microbe-free water of another site. The 2 sites were at Albany (high allochthonous DOM) and NYC (lower terrestrial DOM), and 3 experiments were conducted in 1999, 2000, and 2001. These 2 sites significantly differed ( $p<0.05$; ANOVA) in ambient activity of most ectoenzymes (Table 1 ) and in the 2 most abundant bacterial groups, the alpha- and beta-proteobacteria (Fig. 2). Bacterial abundance at these 2 sites did not differ substantially, and any difference in abundance in the inoculum was small compared to growth during the experiments.

As with the in situ data, nearly all variables differed significantly due to the inoculum, source of water, and/or date of the experiment (Table 2). Both source of the water and of the inoculum affected ectoenzyme activity, with the exception of N-acetylglucosaminidase, which was not significantly affected by either the inoculum or the water. In addition, xylosidase activity was not affected by the water source, whereas 3 enzymes (alpha-glucosidase, esterase and trypsin) were not affected by source of the inoculum. Some of this enzyme activity may have been in the dissolved phase, but any difference in the initial dissolved enzyme activity would not affect our results because bacteria grew and enzyme activity increased several fold during the experiments. In short, 5 enzymes were affected by the water source, whereas 4 were affected by the inoculum source in the switch experiments (Table 2).

Principal component analysis (PCA) indicates that water source is the predominant factor driving vari-

Table 2. Summary of ANOVA analysis for the upstreamdownstream switch experiment conducted during August/ November of 1999, 2000 and 2001. The probability of a Type II error is given ( $p$-values). The 3 independent variables include source of the water and inoculum, and date of the experiment. Eub338 is the general bacterial probe

\begin{tabular}{|lccc|}
\hline Dependent variables & \multicolumn{3}{c|}{ p-values for } \\
& independent variables \\
& Water & Inoculum & Date \\
\hline Alpha-glucosidase & 0.00 & 0.18 & $<0.001$ \\
Beta-glucosidase & 0.09 & 0.02 & $<0.001$ \\
N-acetylglucosaminidase & 0.19 & 0.18 & $<0.001$ \\
Xylosidase & 0.70 & $<0.001$ & $<0.001$ \\
Phosphatase & $<0.001$ & 0.03 & $<0.001$ \\
Leucinaminopeptidase & $<0.001$ & 0.00 & $<0.001$ \\
Esterase & $<0.001$ & 0.47 & $<0.001$ \\
Trypsin & 0.01 & 0.23 & $<0.001$ \\
Leu production & $<0.001$ & $<0.001$ & $<0.001$ \\
TdR production & $<0.001$ & 0.03 & $<0.001$ \\
Eub338 & 0.08 & 0.32 & 0.01 \\
Alpha-proteobacteria & 0.01 & 0.24 & 0.12 \\
Beta-proteobacteria & $<0.001$ & 0.01 & $<0.001$ \\
Gamma-proteobacteria & $<0.001$ & 0.08 & 0.40 \\
Cytophaga-like & $<0.001$ & 0.95 & $<0.001$ \\
\hline
\end{tabular}

ability in enzyme activity (Fig. 3A). There was a significant difference in PC1 scores among water sources (1way ANOVA, $p=0.038$ ) but no significant effect of inoculum (Fig. 3A). Enzyme activity in NYC water (regardless of inoculum) differed significantly from the Albany water source, with both NYC water treatments scoring lower on PC1 than the Albany water. There was no significant difference among water sources for scores on PC2, and the inoculum source had little effect on PCA scores; the reciprocal inocula overlapped on both axes. The PCA analyses suggest that the water was more important than the inoculum in shaping overall ectoenzyme activity.

Bacterial community structure, as revealed by FISH, also changed in the switch experiments. Table 3 sum-
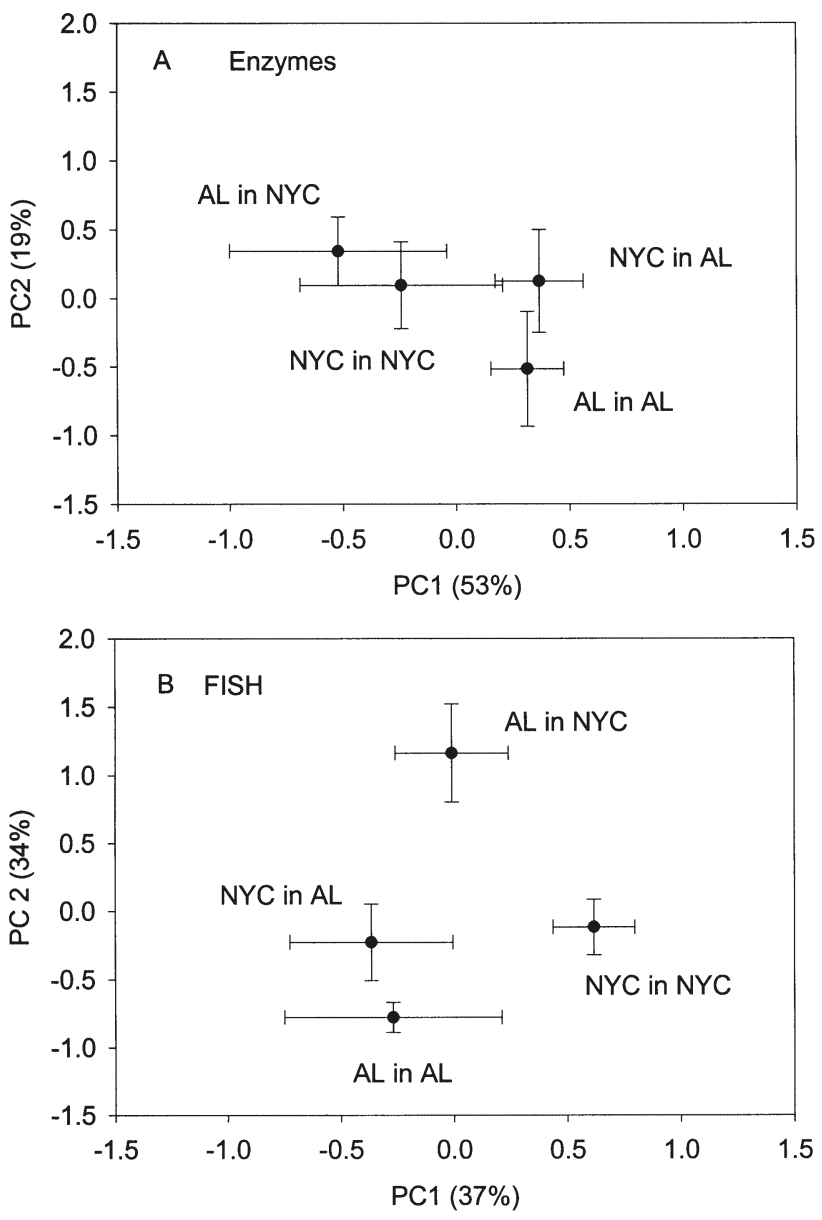

Fig. 3. Principal component analysis of the upstreamdownstream switch experiment. (A) Ectoenzyme activity; (b) bacterial community structure (fluorescence in situ hybridization; FISH). The water and inoculum were taken from Albany (AL) and New York City (NYC). The labeling convention is 'inoculum in water'. For example, 'AL in NYC' indicates that the inoculum was from Albany and the water was from New York City. Values in parentheses show the \% of total variation associated with each principal component 
marizes the changes in all 3 experiments. The relative number of bacteria detectable by FISH increased in all 3 experiments; the number of Eub338-positive cells often increased by as much as $50 \%$ (Table 3) and approached $80 \%$, regardless of the water and inoculum. Neither water nor the inoculum had a significant impact, however, on the relative number of Eub338positive cells, although date of the experiment did (Table 2).

As with enzyme activity, source of water appeared to have a greater impact than the inoculum on bacterial community structure, although the influences varied among the 4 bacterial groups we examined. The water source had a significant effect on the alpha-proteobacterial abundance, but the inoculum source and experiment date did not (Table 2). Beta-proteobacteria were affected significantly by all 3 variables, whereas only the water source had a significant impact on gamma-proteobacterial abundance. In contrast, the Cytophaga-like bacteria were affected significantly by both water source and experiment date, but not by the inoculum. In short, the water source had a significant effect on all 4 bacterial groups, whereas the inoculum source had a statistically significant effect on only beta-proteobacterial abundance.

The PCA analysis suggested that sources of both the water and inoculum had roles in shaping the bacterial community growing up in these experiments. Scores on PC2 differed significantly ( $p<0.001)$ among source waters (Fig. 3B), but the inoculum effect was not significant. There was a significant interaction term in the 2-way ANOVA ( $p=0.001)$, with the Albany inoculum in NYC water significantly separated from other treatments. Therefore, in contrast to the ectoenzyme data, which were affected mostly by the water, the bacterial community structure that developed in these experiments was affected by both the water and the inoculum.

The ANOVA and PCA analyses combined all data and cannot be used to examine the fate of different inocula added to the same water. To do so, the 2 water sources were analyzed separately to determine whether ectoenzyme activity and bacterial community structure developing in incubations with bacteria from 2 different endmembers added to the same water converged to the same levels of activity and community structure. In the NYC water experiments, the bacterial assemblages resulting from the 2 inocula (NYC and Albany) differed significantly in beta-glucosidase, xylosidase, and peptidase activities and in leucine incorporation at the end of the experiment (Fig. 4; p < 0.05; ANOVA). The activity of $\mathrm{N}$ acetylglucosaminidase was marginally significant $(p=0.056)$, whereas the other enzymes did not differ significantly $(p>0.05)$. There was no significant difference in the final abundance of the 4 bacterial groups when either Albany or NYC bacteria were added to NYC water (data not shown). Similarly, in the experiments with Albany water, ultimate activities for phosphatase and aminopeptidase differed significantly for the assemblages grown from the 2 inocula ( $\mathrm{p}<0.05$; ANOVA); activity of the other enzymes was the same at the end of the experiments in which either Albany or NYC bacteria were added to Albany water (data not shown). Both leucine and thymidine incorporation rates also differed signifi-

Table 3. Changes in community structure as revealed by fluorescence in situ hybridization (FISH) in bacteria ('inoculum') added to filter-sterilized water ('water') from the indicated locations. The initial relative abundance in each bacterial group observed in the inoculum was subtracted from the final relative abundance (fraction of total direct counts). A positive number indicates that the group increased in abundance relative to the inoculum; a negative number indicates that it decreased. Eub338 is the general bacterial probe. Alpha, beta, and gamma are subdivisions of the proteobacteria. Cytophaga refers to a complex group of microbes identified by the CF319a probe often referred to as the Cytophaga-Flavobacter or Cytophaga-like group. AL: Albany; NYC: New York City. SE in parentheses

\begin{tabular}{|c|c|c|c|c|c|c|c|}
\hline \multirow{2}{*}{$\begin{array}{l}\text { Date } \\
\text { (mm/yy) }\end{array}$} & \multicolumn{7}{|c|}{ Change in community composition ( $\%$ of total abundance) } \\
\hline & Water & Inoculum & Eub338 & Alpha & Beta & Gamma & Cytophaga \\
\hline $11 / 99$ & $\mathrm{AL}$ & $\mathrm{AL}$ & $17(4.2)$ & $-22.1(0.5)$ & $-7.6(5.2)$ & $-25.4(1.1)$ & $-26.4(1.1)$ \\
\hline $11 / 99$ & $\mathrm{AL}$ & NYC & $24(5.6)$ & $11.9(12.4)$ & $20.4(2.6)$ & $8.1(4.7)$ & $-4.4(9.0)$ \\
\hline $11 / 99$ & NYC & AL & $41(2.3)$ & $25.2(21.1)$ & $-7.7(1.4)$ & $32.3(14.9)$ & $7.5(24.7)$ \\
\hline $11 / 99$ & NYC & NYC & $30(1.8)$ & $1.7(8.0)$ & $12.4(2.5)$ & $7.4(7.7)$ & $-12.4(4.2)$ \\
\hline 08/00 & $\mathrm{AL}$ & $\mathrm{AL}$ & $20(7.0)$ & $1.8(1.7)$ & $47.2(9.2)$ & $-5.1(0.7)$ & $5.1(4.2)$ \\
\hline 08/00 & $\mathrm{AL}$ & NYC & 37 (8.6) & $0.2(0.7)$ & $26.9(7.1)$ & $-4.7(3.2)$ & $3.2(2.6)$ \\
\hline 08/00 & NYC & $\mathrm{AL}$ & $52(2.1)$ & $18.7(8.5)$ & $50.2(3.4)$ & $-1.2(5.9)$ & $4.0(2.3)$ \\
\hline 08/00 & NYC & NYC & $38(3.4)$ & $0.5(0.9)$ & $39.4(8.2)$ & 7.9 (8.3) & $1.7(1.9)$ \\
\hline 09/01 & $\mathrm{AL}$ & $\mathrm{AL}$ & $30(4.0)$ & $-1.7(1.6)$ & $42.8(7.2)$ & $-0.5(1.4)$ & $15.7(16.0)$ \\
\hline 09/01 & $\mathrm{AL}$ & NYC & $42(0.4)$ & $-25.7(3.5)$ & $58.5(3.8)$ & $-0.3(2.0)$ & $52.4(12.4)$ \\
\hline 09/01 & NYC & $\mathrm{AL}$ & $38(2.8)$ & $16.3(10.7)$ & $40.6(23.2)$ & $56.9(10.5)$ & $69.6(5.4)$ \\
\hline 09/01 & NYC & NYC & 31 (4.5) & $-11.4(2.0)$ & $35.4(3.0)$ & $40.5(3.2)$ & $48.9(0.5)$ \\
\hline
\end{tabular}



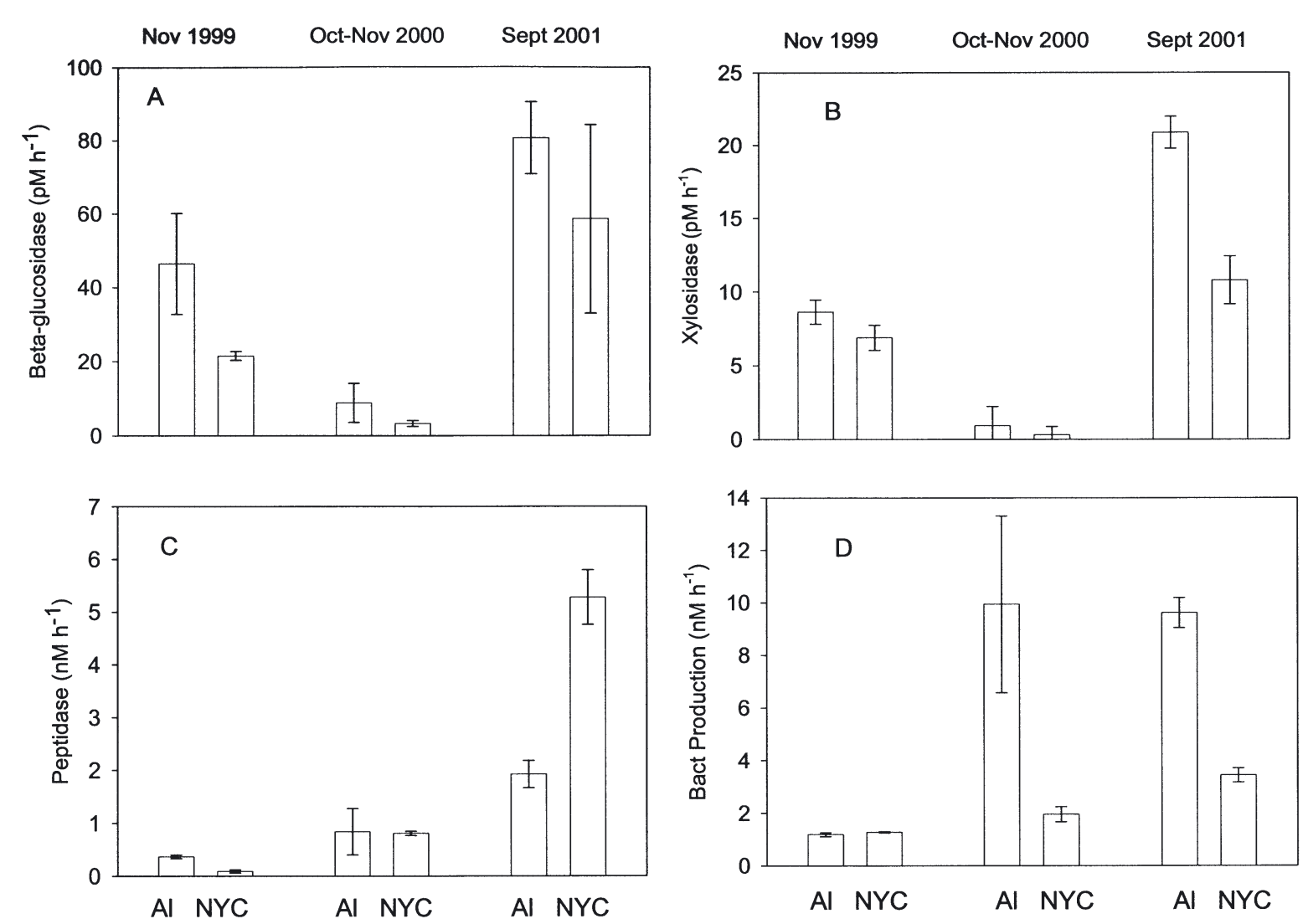

Fig. 4. Activity of ectoenzymes and leucine incorporation (bacterial production) of Albany (AL) or New York City (NYC) bacteria added to NYC water for 3 experiments. Mean \pm SD of 3 replicate bottles are given. The differences between the 2 inocula are statistically significant when all dates are analyzed together $(\mathrm{p}<0.05$; ANOVA)

cantly with inocula for the Albany water experiments. Unlike the NYC water experiments, the abundance of both alpha- and beta-proteobacteria remained different in the Albany water experiments with both inocula, even after 3 to $4 \mathrm{~d}$ of incubation (data not shown).

Enzyme activity in incubations with the Albany inoculum was generally higher than for the NYC inoculum incubations, even for Albany bacteria added to NYC water (Fig. 4). Likewise, leucine incorporation rates were 5 -fold higher in 2 of 3 experiments for Albany bacteria added to NYC water (Fig. 4); thymidine incorporation rates were 2-fold higher for Albany bacteria than for NYC bacteria added to Albany water in 2 of 3 experiments (data not shown). The higher level of activity for the Albany bacteria reflects the initial difference between the 2 sites; rates of most of the enzymes and leucine incorporation were higher in the ambient water at Albany than at NYC (Table 1). In short, some differences in enzyme activity, biomass production, and community structure remained even after several days of incubation of different inocula added to the same water.

\section{Tributary experiments}

To explore further the role of water source (and thus DOM characteristics) in shaping bacterial activity and community structure, we added a single inoculum from the Hudson River main stem at Norrie Point to water from 3 tributaries and 1 location in the upper Hudson above the tidal influence (Waterford). Of the 8 ectoenzymes, 3 varied significantly due to the water source: beta-glucosidase, esterase, and trypsin ( $p<$ 0.001; ANOVA). Although the impact on individual ectoenzymes was relatively minor, the overall effect was large, according to the PCA analyses (Fig. 5A) with significantly different scores on PC1 (ANOVA, $p=$ 0.02). The first PC score for the Waterford source water (upper Hudson, above tidal portion) was significantly different from that of the 3 other locations, and the score for the Mohawk source water was significantly different from the Wallkill (Fig. 5A). None of the sources had significantly different scores on the second principal component.

The water source also had a large overall impact on bacterial community structure, as revealed by FISH, 

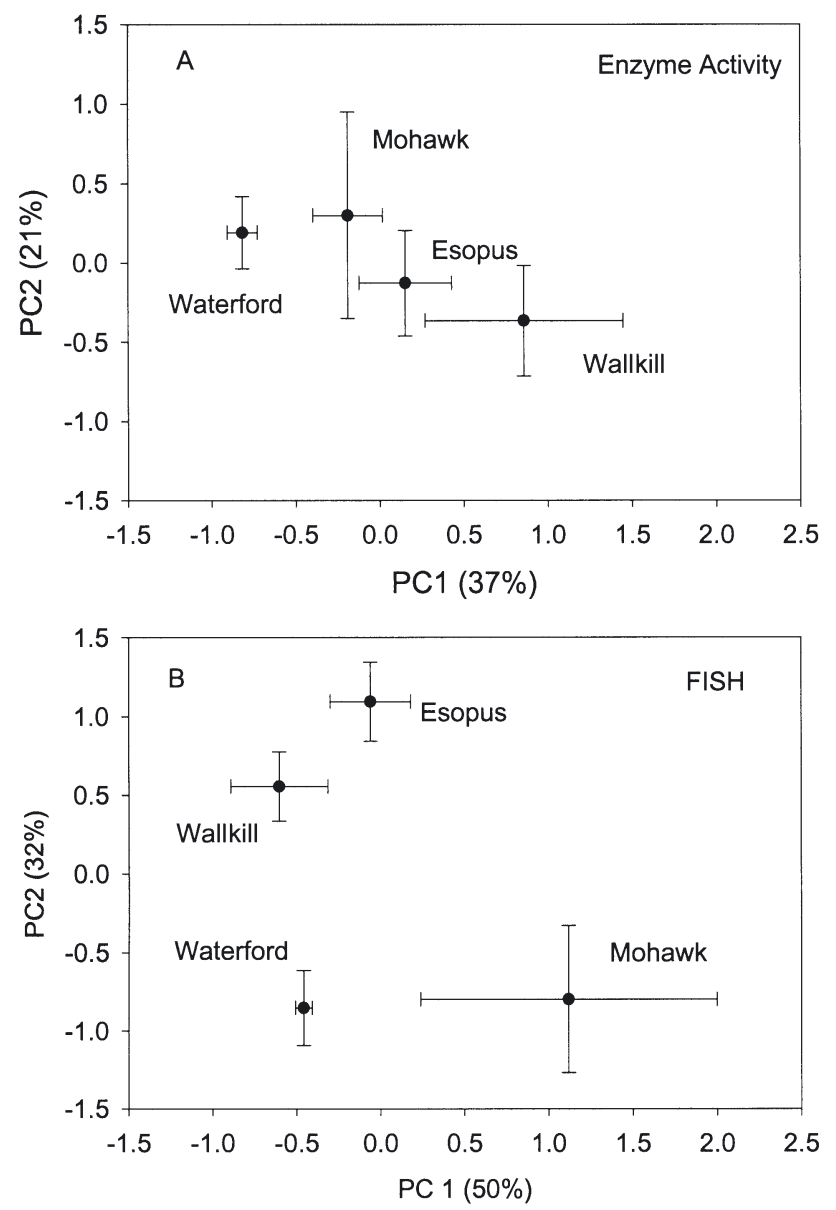

Fig. 5. Principal component analysis of the tributary experiment. (A) Ectoenzyme activity; (B) bacterial community structure (fluorescence in situ hybridization; FISH). Enzyme data are from 2 experiments conducted from October to November 2000 and October 2001. The FISH data are from the October 2001 experiment only

although the absolute change in most of the bacterial groups was small. The beta-proteobacteria were the most abundant group in these experiments (Fig. 6), but water source did not have a significant effect on their abundance ( $p>0.05$; ANOVA). Alpha-proteobacteria were the least abundant group $(<5 \%$ of total abundance) and were also not affected by the water source. The water source had a marginally significant effect on gamma-proteobacterial abundance $(\mathrm{p}=0.055$; ANOVA), and a post-hoc test revealed that abundance of this group in the Esopus and Waterford waters differed significantly ( $\mathrm{p}=0.017$; Tamhane's test). Cytophaga-like bacteria, which, along with gammaproteobacteria, were second in abundance to betaproteobacteria (Fig. 6), were significantly affected by the water source $(\mathrm{p}<0.001$; ANOVA). The post-hoc test indicated that final Cytophaga-like bacterial abundance in these experiments differed significantly in water from the Esopus and Mohawk; abundance of this group was higher and lower, respectively, than the abundances in water from the other tributaries $(p<$ 0.001).

While the effect of water source on the abundance of individual bacterial groups was rather minimal in this tributary experiment, the overall effect was large, as revealed by significant differences in PC2 scores $(\mathrm{p}=$ 0.005). The Mohawk and Waterford sources differed significantly in PC2 scores from the Wallkill and Esopus sources (Fig. 5B), although none of the water sources had significantly different PC1 scores. The PCA analyses indicated that the community growing up in the Esopus water was similar to that in the Wallkill water, and both differed greatly from the Waterford and Mohawk waters (Fig. 5B).

\section{Ectoenzyme activity and bacterial community structure}

We used 2 statistical approaches to explore the relationships between ectoenzyme activity and bacterial community structure. These analyses were applied to
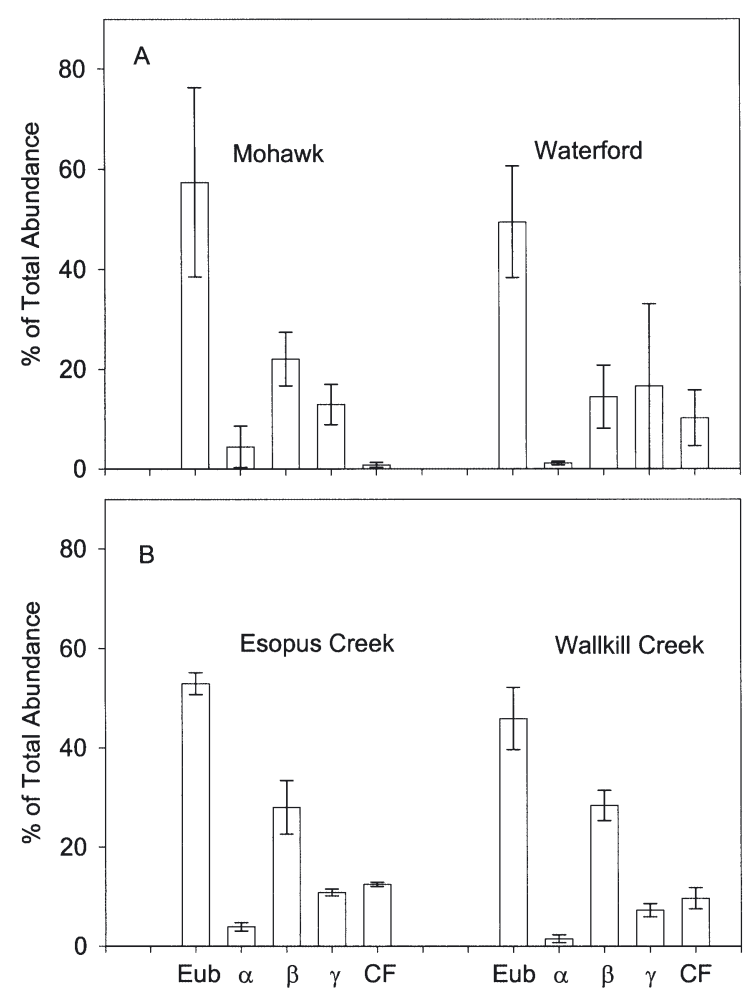

Fig. 6. Bacterial community structure in the tributary experiment of October 2001. The inoculum was from the Hudson River at Norrie Point. Greek letters refer to subdivisions of proteobacteria, CF is the Cytophaga-Flavobacterium group, and Eub refers to those bacteria detected by the general bacterial probe Eub338. Mean \pm SE are given for 3 replicate bottles 
the entire data set (ambient and experiments) in order to increase our sample size and to help ensure the generality of our results. Not unexpectedly, the activities of several ectoenzymes were positively correlated with each other (Table 4). A notable exception is trypsin activity, which was not significantly correlated with any of the other ectoenzymes. It is surprising how few of the ectoenzymes correlated significantly with the 2 measures of biomass production (leucine and thymidine incorporation).

Only a few of the bacterial groups we examined covaried significantly with each other (Table 4). Two of the proteobacterial subdivisions, alpha- and gammaproteobacteria, correlated significantly $(r=0.477$; $p<$ 0.001), whereas the beta-proteobacteria strongly covaried with Cytophaga-like bacteria $(\mathrm{r}=0.775 ; \mathrm{p}<$ 0.001). There was no significant correlation between alpha- and beta-proteobacterial abundances $(\mathrm{r}=$ $-0.032 ; \mathrm{p}>0.05)$.

Several of the ectoenzymes and the 2 measures of bacterial production covaried significantly with the abundance of 1 or more of the 4 bacterial groups examined here (Table 4). The abundance of alphaproteobacteria was positively correlated with 5 of the 8 ectoenyzmes; alpha-glucosidase, N-acetylglucosaminidase, and esterase correlations all exceeded 0.5 (Table 4). Of the 2 ectoenzymes that Cytophaga-like bacteria were significantly correlated with (Table 4), the strongest correlation was with $\mathrm{N}$-acetylglucosaminidase activity $(r=0.503 ; \mathrm{p}<0.0001)$. Gammaproteobacterial abundance was significantly correlated with only esterase activity $(r=0.399 ; \mathrm{p}<0.001)$.
Leucine incorporation was positively correlated with the abundance of alpha- and gamma-proteobacteria, but thymidine incorporation was only negatively correlated with beta-proteobacteria.

Perhaps the most interesting correlation is that between beta-proteobacteria and phosphatase activity. This bacterial group was significantly correlated with only 1 ectoenzyme (phosphatase), but the correlation coefficient was the highest of any of the pairwise comparisons between the bacterial groups and ectoenzyme activity $(\mathrm{r}=0.718)$. The correlation appears to be determined by 2 groups of samples, one with low phosphatase activity and relative betaproteobacterial abundance, and another with high values (Fig. 7). With only 2 exceptions, the samples with high phosphatase activity and high relative betaproteobacterial abundance were from the switch experiment with Albany water, to which Albany or NYC bacteria were added.

To further explore the relationship between community structure and ectoenzyme activity, we performed a multi-variate linear regression using the various ectoenzymes as the dependent variable (one at a time) and the 4 bacterial groups as the independent variables (all together). Nearly all of the regression models explained a significant amount of variation, although only a few explained more than $40 \%$ for a particular ectoenzyme activity (Table 5). As revealed by the correlation analysis, beta-proteobacterial abundance was the sole bacterial group accounting for (in a positive sense) a significant amount of the variation in phosphatase activity; alpha- and gamma-proteobacteria

Table 4. Correlation coefficients for the entire data set. Missing values were eliminated list-wise, resulting in $\mathrm{N}=57 .{ }^{*} \mathrm{p}=0.05 / 15=0.003$ (or better), using the Bonferroni adjustment. Correlation coefficients $>0.5$ in bold. Abbreviations: $\alpha$-glcase = alpha-glucosidase; $\beta$-glcase = beta-glucosidase $;$ NAGase $=$ N-acetylglucosaminase $;$ P-ase $=$ phosphatase $;$ Pep-ase $=$ aminopeptidase $;$ Est-ase $=$ esterase $;$ Eub338 $=$ fraction of all cells hybridized by the general bacterial probe; Alpha, Beta, and Gamma = fraction of cells in these 3 proteobacterial subdivisions. CF-like refers to the Cytophaga-Flavobacterium cluster. Fluorescence in situ hybridization (FISH) data were arcsin transformed before analysis

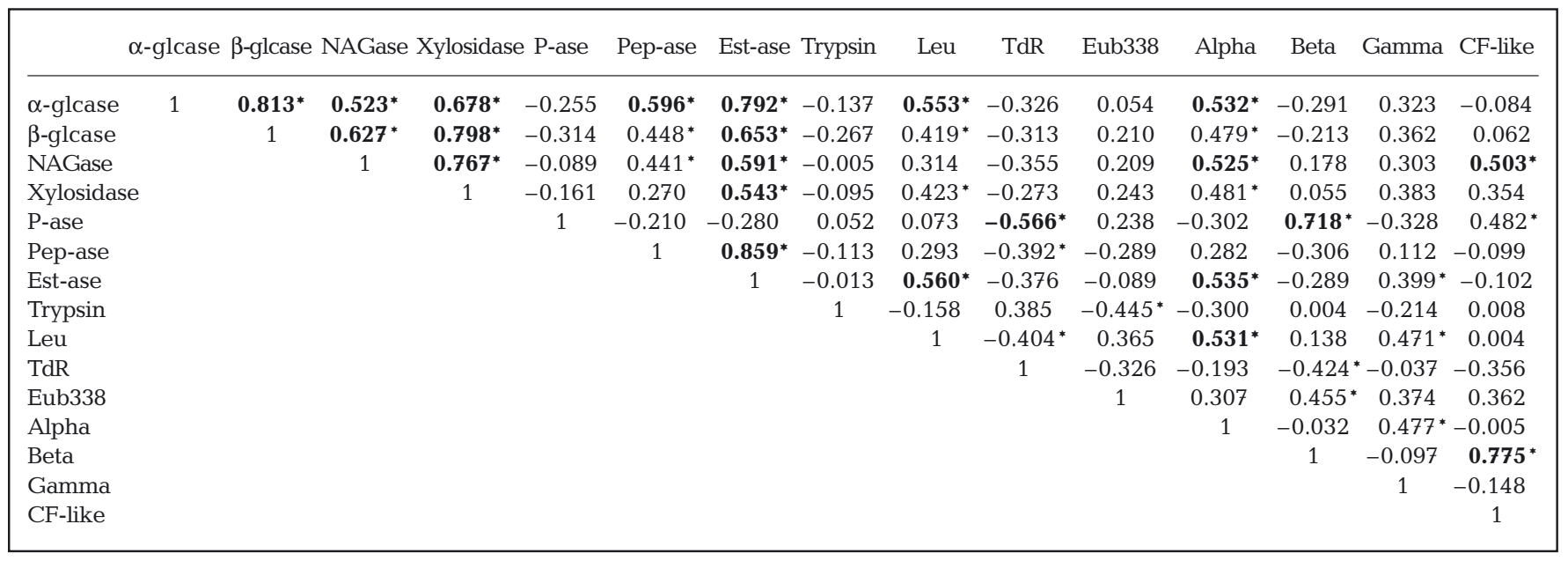




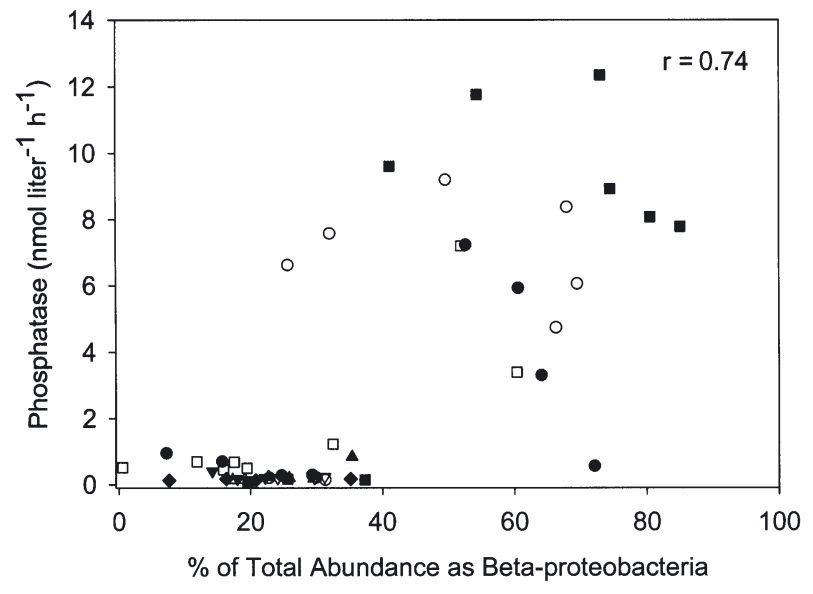

Fig. 7. Relationship between phosphatase activity and the relative abundance of beta-proteobacteria (\% of total abundance) for the entire data set $(r=0.74 ; p<0.001)$. Ambient data from all sites are indicated by diamonds $(\bullet)$, whereas the upstream-down stream switch experiments were as follows:

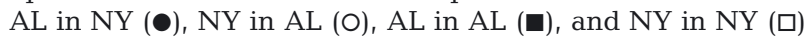
(see Fig. 3 legend for explanation). Tributary experiments are indicated by Esopus $(\mathbf{\Lambda})$, Mohawk $(\Delta)$, Wallkill $(\boldsymbol{\nabla})$, and Waterford $(\nabla)$

had weak, negative relationships with phosphatase activity. The regression model explained over $60 \%\left(\mathrm{r}^{2}\right.$ $>0.6$ ) of the variation in phosphatase activity (Table 5).

The abundance of Cytophaga-like bacteria, however, was the dominant variable in the regression models for 3 other ectoenzymes: beta-glucosidase, $\mathrm{N}$-acetylglucosaminidase, and xylosidase (Table 5). In particular, for $\mathrm{N}$-acetylglucosaminidase, the standardized coefficient for Cytophaga-like bacterial abundance $(0.878)$ was over twice that of the next mostimportant bacterial group (0.383). The regression model with the 4 bacterial groups explained $61 \%$ of the variation in $\mathrm{N}$-acetylglucosaminidase activity (Table 5). The alpha-proteobacterial abundance was second in importance for these ectoenzymes, but it was the dominant variable in explaining the variation in alpha-glucosidase activity. The abundance of betaproteobacteria had a negative effect on all ectoenzymes, except phosphatase activity, according to this analysis (Table 5). This regression analysis implies an important role for Cytophaga-like bacteria in determining the activity of several ectoenzymes.

Community structure did not explain any significant variation in the activity of the 2 proteases, aminopeptidase and trypsin, the only 2 enzymes for which community structure appears to have no role (Table 5).

\section{DISCUSSION}

Concentrations and composition of DOM, bacterial community structure and, undoubtedly, other factors interact in complicated ways to determine ectoenzymatic activity, which drives DOM hydrolysis and eventually mineralization of DOM by heterotrophic bacteria in aquatic ecosystems. Our approach for exploring these issues was to examine ectoenzyme activity and community structure in experiments with water and inocula from locations in the Hudson that differ in DOM concentrations and composition. Although the water sources differed in other respects, DOM was likely the main factor affecting bacteria in these experiments. Inorganic nutrients were probably not important factors, because concentrations were sufficiently high to prevent $\mathrm{N}$ or $\mathrm{P}$ limitation and because bacterial growth is primarily limited by the supply of organic carbon in the Hudson River (Roland \& Cole 1999). The impact of particulate organic carbon and detritus was

Table 5. Linear regression analysis of the contribution of the major bacterial groups (alpha-, beta, and gamma-proteobacteria and Cytophaga-like bacteria [CF]) to the variation in bacterial production (thymidine [TdR] and leucine [leu] incorporation) and enzyme activity. The entire data set was used in the data analysis. 'NS' indicates the coefficient is not statistically significant ( $p>$ 0.05). Standardized coefficients measure the contribution by the bacterial group to explaining variation in the dependent variables. Parameters higher than 0.60 are in bold. NS: not significant

\begin{tabular}{|c|c|c|c|c|c|c|}
\hline \multirow{2}{*}{ Dependent variables } & \multicolumn{4}{|c|}{ Standardized coefficients } & \multicolumn{2}{|c|}{ Adjusted } \\
\hline & Alpha & Beta & Gamma & $\mathrm{CF}$ & $\mathrm{r}^{2}$ & $\mathrm{p}$ \\
\hline TdR incorporation & NS & -0.388 & NS & NS & 0.165 & $9.2 \times 10^{-3}$ \\
\hline Leu incorporation & 0.382 & 0.436 & 0.281 & NS & 0.353 & $5.8 \times 10^{-6}$ \\
\hline Alpha-glucosidase & 0.436 & -0.449 & NS & NS & 0.317 & $2.6 \times 10^{-5}$ \\
\hline Beta-glucosidase & 0.307 & -0.561 & 0.262 & 0.536 & 0.340 & $1.0 \times 10^{-5}$ \\
\hline N-acetylglucosaminidase & 0.383 & -0.450 & 0.227 & 0.878 & 0.606 & $5.3 \times 10^{-12}$ \\
\hline Phosphatase & -0.183 & 0.872 & -0.183 & NS & 0.624 & $1.3 \times 10^{-12}$ \\
\hline Xylosidase & 0.312 & -0.535 & 0.271 & 0.768 & 0.447 & $7.3 \times 10^{-8}$ \\
\hline Esterase & 0.415 & -0.387 & NS & NS & 0.332 & $1.4 \times 10^{-5}$ \\
\hline Aminopeptidase & NS & -0.402 & NS & NS & 0.080 & $>0.05$ \\
\hline Trypsin & NS & NS & NS & NS & 0.043 & $>0.05$ \\
\hline
\end{tabular}


not examined here, although this form of carbon could impact the structure of in situ bacterial communities (DeLong et al. 1993) and of the inocula for our experiments.

Our experimental design ( 2 to $3 \mathrm{~d}$ incubations in bottles with diluted microbial assemblages) has limitations, such as possibly favoring the growth of microbes quite different from the initial community. Both community structure and enzymatic activity changed from initial values, even in incubations with the water and inoculum from the same source (the 'controls'). These changes complicate attempts to understand the impact of terrestrial DOM on community structure and enzyme activity, but the comparison among DOM and inoculum sources still allowed examination of the relative strength of these factors in affecting community structure and activity. Even if some of the changes in controls were due to bottle effects, and even though it is difficult to relate effects observed in bottle incubations to in situ processes, the data can still be used to explore interactions between DOM and bacterial community structure, and to examine basic questions about the controls on activity and community composition in the Hudson.

Our experiments illustrate the impact of DOM on bacterial community structure, and suggest that community structure (at the phylogenetic level we assayed) did not constrain the activity of some of the ectoenzymes examined here. Activity of some ectoenzymes of communities derived from disparate inocula converged to similar rates, even when grown in the same water from either NYC or Albany. Thus, the water and, presumably, DOM generally overrode differences in initial community structure in determining final enzyme activities. The PCA analysis indicated that the water, i.e. DOM, affected community structure more strongly than it affected ectoenzyme activity, since there were significant differences in both principal components for the FISH data but only in one component for the ectoenzyme data in the tributary experiment. These data suggest that the activity of some ectoenzymes and, thus, the hydrolysis of some DOM components may not depend strongly on bacterial community structure.

However, other analyses point to a dependence of some ectoenzymes on bacterial community structure. The rates of some ectoenzymes did not converge when NYC and Albany inocula were added to either NYC or Albany water. The rates of some ectoenzymes (and of leucine and thymidine incorporation) were higher in incubations with Albany bacteria than with NYC bacteria, even in NYC water. This difference parallels the initial difference in activity of the in situ bacterial communities; like in the experiments, metabolic activity of Albany bacteria was generally higher than that of NYC bacteria in situ. Since the 3 to $4 \mathrm{~d}$ incubations should have been long enough for any phenotypic response by the bacterial community, the persistent difference in activity in our incubations suggest that bacterial communities are not equally capable of expressing all ectoenzymes necessary for hydrolyzing DOM. Changes in community structure may sometimes be required before new DOM is hydrolyzed, and perhaps ultimately mineralized.

Other data further illustrate possible impacts of community structure on ectoenzyme activity. We found several significant correlations between enzyme activity and the abundances of the 4 bacterial groups we examined, with the strongest being between betaproteobacterial abundance and phosphatase activity. If beta-proteobacteria do in fact have more active phosphatases, as suggested by the correlation analysis, it may explain their high abundance in freshwater systems (Glöckner et al. 1999), which are often limited by phosphorus (Wetzel 2001). Also, the multi-variate regression models using bacterial community structure explained a significant amount of variation in the activity of all ectoenzymes, except the 2 proteases. Although it is difficult to extrapolate from these statistical analyses to causal relationships, the data imply that the major bacterial groups we examined differ in ectoenzyme activity. Other evidence also points to differences in DOM uptake among the bacterial groups we examined, that is, the alpha-, beta-, and gammaproteobacteria and the Cytophaga-Flavobacterium cluster. These 4 groups appear to differ in their response to changing DOM supply and composition in field studies and experiments (Rossello-Mora et al. 1999, Eilers et al. 2000a, 2001). Also, uptake of several DOM components differs among these 4 bacterial groups (Cottrell \& Kirchman 2000, Malmstrom et al. 2004). These differences may explain why alphaand beta-proteobacteria and Cytophaga-like bacteria responded differently in mesocosms that varied in primary production (Horner-Devine et al. 2003).

It is surprising that the relationships between DOM and the major bacterial groups appear to differ and, more specifically, that the relationship between abundance and ectoenzyme activity varied among the bacterial groups we examined. Each of these groups is potentially diverse, consisting of many 'species' or ribotypes (Giovannoni \& Rappé 2000). One may expect that these bacterial groups would be sufficiently large and diverse so that all ectoenzymes are potentially expressed by a single group. Consequently, enzyme activity should not differ between broad bacterial groups, even if individual ribotypes do (Martinez et al. 1996). It is possible, however, that each broad group may actually be represented by a small number of dominant ribotypes in any given environmental 
sample at a particular time. Differences in ectoenzymatic activity at the ribotype level would become apparent even when measured at the division and subdivion level if the bacterial groups in our samples were not very diverse. In support of this hypothesis, preliminary data from denaturing gradient gel electrophoresis (DGGE) analyses (Muyzer \& Smalla 1998) indicate that the bacterial communities had on the order of 10 dominant ribotypes in our experiments. If divided equally among the 4 bacterial groups examined here, the DGGE and FISH data suggest that each group is represented by only ca. 2 to 3 dominant ribotypes, although several other less abundant ribotypes $(<10 \%)$ may also be present.

Regardless of exactly how bacterial community structure is linked to DOM use, the existence of any link suggests that community structure could have an impact on DOM mineralization. The nature and extent of this impact are likely to vary with the factors that control community structure, and the effect may be substantial when heterotrophic bacteria are limited by factors other than DOM. These other factors include inorganic nutrients such as phosphate and iron (Pakulski et al. 1996, Cotner et al. 1997), grazing (Šimek et al. 1997, Suzuki 1999, Riemann et al. 2000, Pernthaler et al. 2001, Beardsley et al. 2003, Cottrell \& Kirchman 2004), viral lysis (Fuhrman 2000), temperature (Pomeroy \& Wiebe 2001), and other abiotic factors (del Giorgio \& Bouvier 2002). Previous studies have also shown how factors other than DOM can affect community structure (Gasol et al. 2002, Šimek et al. 2003). If a bacterial group specializing in using some DOM components is limited by one of these other factors, then degradation of those components may also be affected indirectly.

Even the composition of a DOM-controlled bacterial community could have short-term (days) impacts on DOM degradation when DOM concentrations or composition change enough to induce changes in bacterial metabolism. Our results suggest that not all bacterial communities are equally capable of maximal ectoenzyme activity and perhaps of effective DOM mineralization when the DOM pool changes. Even after several days, the activity of some ectoenzymes was not as high for the NYC inoculum, for example, as observed for the Albany inoculum in the same water. For those ectoenzymes, a change in the bacterial community appeared necessary before hydrolysis of those targeted DOM components could be maximal. These results suggest that community structure could control degradation of some DOM components.

Such control by bacterial community structure is one level at which DOM mineralization is regulated, with the other extreme being the kinetic response of already synthesized enzymes (Sinsabaugh \& Findlay
2003). Rates of constitutive enzymes can respond quite rapidly, on the order of minutes to hours, whereas days may be required for a rare ribotype to increase sufficiently in abundance before appreciably affecting DOM mineralization at the community level (Findlay 2003). In between these 2 extremes is induction and synthesis of new enzymes, which occur within hours. All of these levels undoubtedly contribute to regulating DOM mineralization, and the contributions probably vary with the seasons and habitats. How DOM mineralization is regulated will set the time scale for DOM mineralization and biomass production, which in turn will affect storage of $\mathrm{C}$ in DOC and transport of DOM from more productive to less productive regions, such as from rivers and estuaries to the oceans.

Acknowledgements. We thank Liying Yu for technical help, Matthew Cottrell for his input during all aspects of this project and Pam Nilsen for drafting Fig. 1. This work was supported by Grant 009/99A from the Hudson River Foundation and the National Science Foundation (OCE-9908808).

\section{LITERATURE CITED}

Amann RI, Krumholz L, Stahl DA (1990) Fluorescent-oligonucleotide probing of whole cells for determinative, phylogenetic, and environmental studies in microbiology. J Bacteriol 172:762-770

Amann RI, Ludwig W, Schleifer KH (1995) Phylogenetic identification and in situ detection of individual microbial cells without cultivation. Microbiol Rev 59:143-169

Amon RMW, Benner R (1994) Rapid cycling of high-molecular-weight dissolved organic matter in the ocean. Nature 369:549-552

Amon R, Benner R (1996) Bacterial utilization of different size classes of dissolved organic matter. Limnol Oceanogr 41: 41-51

Arnosti C (2003) Microbial extracellular enzymes and their role in dissolved organic matter cycling. In: Findlay SEG, Sinsabaugh RL (eds) Aquatic ecosystems: interactivity of dissolved organic matter. Academic Press, San Diego, p 315-342

Beardsley C, Pernthaler J, Wosniok W, Amann R (2003) Are readily culturable bacteria in coastal North Sea waters suppressed by selective grazing mortality? Appl Environ Microbiol 69:2624-2630

Benner R (2002) Chemical composition and reactivity. In: Hansell DA, Carlson CA (eds) Biogeochemistry of marine dissolved organic matter. Academic Press, New York, p 59-90

Benner R (2003) Molecular indicators of bioavailability of dissolved organic matter. In: Findlay SEG, Sinsabaugh RL (eds) Aquatic ecosystems: interactivity of dissolved organic matter. Academic Press, San Diego, p 121-137

Cole JJ, Carpenter SR, Kitchell JF, Pace ML (2002) Pathways of organic carbon utilization in small lakes: results from a whole-lake C-13 addition and coupled model. Limnol Oceanogr 47:1664-1675

Cotner JB, Ammerman JW, Peele ER, Bentzen E (1997) Phosphorus-limited bacterioplankton growth in the Sargasso Sea. Aquat Microb Ecol 13:141-149 
Cotner JB, Johengen TH, Biddanda BA (2000) Intense winter heterotrophic production stimulated by benthic resuspension. Limnol Oceanogr 45:1672-1676

Cottrell MT, Kirchman DL (2000) Natural assemblages of marine proteobacteria and members of the CytophagaFlavobacter cluster consuming low- and high- molecularweight dissolved organic matter. Appl Environ Microbiol 66:1692-1697

Cottrell MT, Kirchman DL (2003) Contribution of major bacterial groups to bacterial biomass production (thymidine and leucine incorporation) in the Delaware Estuary. Limnol Oceanogr 48:168-178

Cottrell MT, Kirchman DL (2004) Phylogenetic composition and size structure of thymidine and leucine-active heterotrophic bacteria in the Delaware estuary. Aquat Microb Ecol 34:139-149

Covert JS, Moran MA (2001) Molecular characterization of estuarine bacterial communities that use high- and lowmolecular weight fractions of dissolved organic carbon. Aquat Microb Ecol 25:127-139

Davey KE, Kirby RR, Turley CM, Weightman AJ, Fry JC (2001) Depth variation of bacterial extracellular enzyme activity and population diversity in the northeastern North Atlantic Ocean. Deep-Sea Res II 48:1003-1017

del Giorgio PA, Bouvier TC (2002) Linking the physiologic and phylogenetic successions in free-living bacterial communities along an estuarine salinity gradient. Limnol Oceanogr 47:471-486

del Giorgio PA, Davis J (2003) Patterns in dissolved organic matter lability and consumption across aquatic ecosystems. In: Findlay SEG, Sinsabaugh RL (eds) Aquatic ecosystems: interactivity of dissolved organic matter. Academic Press, San Diego, p 399-424

DeLong EF, Franks DG, Alldredge AL (1993) Phylogenetic diversity of aggregate-attached versus free-living marine bacterial assemblages. Limnol Oceanogr 38:924-934

Eilers H, Pernthaler J, Amann R (2000a) Succession of pelagic marine bacteria during enrichment: a close look at cultivation-induced shifts. Appl Environ Microbiol 66:4634-4640

Eilers H, Pernthaler J, Glöckner FO, Amann R (2000b) Culturability and in situ abundance of pelagic bacteria from the North Sea. Appl Environ Microbiol 66:3044-3051

Eilers H, Pernthaler J, Peplies J, Glöckner FO, Gerdts G, Amann R (2001) Isolation of novel pelagic bacteria from the German Bight and their seasonal contributions to surface picoplankton. Appl Environ Microbiol 67:5134-5142

Fandino LB, Riemann L, Steward GF, Long RA, Azam F (2001) Variations in bacterial community structure during a dinoflagellate bloom analyzed by DGGE and 16S rDNA sequencing. Aquat Microb Ecol 23:119-130

Findlay SEG (2003) Bacterial response to variation in dissolved organic matter. In: Findlay SEG, Sinsabaugh RL (eds) Aquatic ecosystems: interactivity of dissolved organic matter. Academic Press, San Diego, p 363-379

Findlay S, Pace ML, Lints D, Cole JJ, Caraco NF, Peierls B (1991) Weak coupling of bacterial and algal production in a heterotrophic ecosystem - the Hudson River Estuary. Limnol Oceanogr 36:268-278

Findlay S, Pace M, Fischer D (1996) Spatial and temporal variability in the lower food web of the tidal freshwater Hudson River. Estuaries 19:866-873

Findlay S, Sinsabaugh RL, Fischer DT, Franchini P (1998) Sources of dissolved organic carbon supporting planktonic bacterial production in the tidal freshwater Hudson River. Ecosystems 1:227-239

Findlay SEG, Sinsabaugh RL, Sobczak WV, Hoostal M (2003) Metabolic and structural response of hyporheic microbial communities to variations in supply of dissolved organic matter. Limnol Oceanogr 48:1608-1617

Fuhrman JA (2000) Impact of viruses on bacterial processes. In: Kirchman DL (ed) Microbial ecology of the oceans. Wiley-Liss, New York, p 327-350

Gasol JM, Comerma M, Garcia JC, Armengol J, Casamayor EO, Kojecka P, Šimek K (2002) A transplant experiment to identify the factors controlling bacterial abundance, activity, production, and community composition in a eutrophic canyon-shaped reservoir. Limnol Oceanogr 47:62-77

Giovannoni SJ, Rappé MS (2000) Evolution, diversity and molecular ecology of marine prokaryotes. In: Kirchman DL (ed) Microbial ecology of the ocean. Wiley Interscience, New York, p 47-84

Glöckner FO, Fuchs BM, Amann R (1999) Bacterioplankton compositions of lakes and oceans: a first comparison based on fluorescence in situ hybridization. Appl Environ Microbiol 65:3721-3726

Glöckner FO, Zaichikov E, Belkova N, Denissova L, Pernthaler J, Pernthaler A, Amann R (2000) Comparative 16S rRNA analysis of lake bacterioplankton reveals globally distributed phylogenetic clusters including an abundant group of actinobacteria. Appl Environ Microbiol 66: 5053-5065

Horner-Devine MC, Leibold MA, Smith VH, Bohannan BJM (2003) Bacterial diversity patterns along a gradient of primary production. Ecol Lett 6:613-622

Karner M, Fuhrman JA (1997) Determination of active marine bacterioplankton: a comparison of universal 16S rRNA probes, autoradiography, and nucleoid staining. Appl Environ Microbiol 63:1208-1213

Karner MB, DeLong EF, Karl DM (2001) Archaeal dominance in the mesopelagic zone of the Pacific Ocean. Nature 409: $507-510$

Kirchman DL (2001) Measuring bacterial biomass production and growth rates from leucine incorporation in natural aquatic environments. In: Paul JH (ed) Marine microbiology, Vol. 30. Academic Press, San Diego

Kirchman DL (2002) The ecology of Cytophaga-Flavobacteria in aquatic environments. FEMS Microb Ecol 39:91-100

Malmstrom RR, Kiene RP, Kirchman DL (2004) Identification and enumeration of bacteria assimilating dimethylsulfoniopropionate (DMSP) in the North Atlantic and Gulf of Mexico. Limnol Oceanogr 49:597-606

Manz W, Amann R, Ludwig W, Wagner M, Schleifer KH (1992) Phylogenetic oligodeoxynucleotide probes for the major subclasses of proteobacteria: problems and solutions. Syst Appl Microbiol 15:593-600

Manz W, Amann R, Ludwig W, Vancanneyt M, Schleifer KH (1996) Application of a suite of 16S rRNA-specific oligonucleotide probes designed to investigate bacteria of the phylum Cytophaga-Flavobacter-Bacteroides in the natural environment. Microbiology 142:1097-1106

Martinez J, Smith DC, Steward GF, Azam F (1996) Variability in ectohydrolytic enzyme activities of pelagic marine bacteria and its significance for substrate processing in the sea. Aquat Microb Ecol 10:223-230

McKnight DM, Boyer EW, Westerhoff PK, Doran PT, Kulbe T, Andersen DT (2001) Spectrofluorometric characterization of aquatic fulvic acid for determination of precursor organic material and general structural properties. Limnol Oceanogr 46:38-48

Morris RM, Rappé MS, Connon SA, Vergin KL, Siebold WA, Carlson CA, Giovannoni SJ (2002) SAR11 clade dominates ocean surface bacterioplankton communities. Nature 420: 806-810

Mulholland PJ, Fellows CS, Tank JL, Grimm NB and 9 others 
(2001) Inter-biome comparison of factors controllling stream metabolism. Freshw Biol 46:1503-1517

Muylaert K, Van der Gucht K, Vloemans N, De Meester L, Gillis M, Vyverman W (2002) Relationship between bacterial community composition and bottom-up versus topdown variables in four eutrophic shallow lakes. Appl Environ Microbiol 68:4740-4750

Muyzer G, Smalla K (1998) Application of denaturing gradient gel electrophoresis (DGGE) and temperature gradient gel electrophoresis (TGGE) in microbial ecology. Antonie van Leeuwenhock 73:127-141

Pakulski JD, Coffin RB, Kelley CA, Holder SL, Downer R, Aas P, Lyons MM, Jeffrey WH (1996) Iron stimulation of Antarctic bacteria. Nature 383:133-134

Pernthaler J, Posch T, Šimek K, Vrba J and 5 others (2001) Predator-specific enrichment of actinobacteria from a cosmopolitan freshwater clade in mixed continuous culture. Appl Environ Microbiol 67:2145-2155

Pomeroy LR, Wiebe WJ (2001) Temperature and substrates as interactive limiting factors for marine heterotrophic bacteria. Aquat Microb Ecol 23:187-204

Rappé MS, Giovannoni SJ (2003) The uncultured microbial majority. Annu Rev Microbiol 57:369-394

Riemann L, Steward GF, Azam F (2000) Dynamics of bacterial community composition and activity during a mesocosm diatom bloom. Appl Environ Microbiol 66:578-587

Roland F, Cole JJ (1999) Regulation of bacterial growth efficiency in a large turbid estuary. Aquat Microb Ecol 20: 31-38

Rossello-Mora R, Thamdrup B, Schafer H, Weller R, Amann R (1999) The response of the microbial community of marine sediments to organic carbon input under anaerobic condi-

Editorial responsibility: Karel Šimek,

České Budějovice, Czech Republic tions. Syst Appl Microbiol 22:237-248

Šimek K, Vrba J, Pernthaler J, Posch T, Hartman P, Nedoma J, Psenner R (1997) Morphological and compositional shifts in an experimental bacterial community influenced by protists with contrasting feeding modes. Appl Environ Microbiol 63:587-595

Šimek K, Hornak K, Masin M, Christaki U, Nedoma J, Weinbauer MG, Dolan JR (2003) Comparing the effects of resource enrichment and grazing on a bacterioplankton community of a meso-eutrophic reservoir. Aquat Microb Ecol 31:123-135

Sinsabaugh RL, Findlay SEG (2003) Dissolved organic matter: out of the black box and into the mainstream. In: Findlay SEG, Sinsabaugh RL (eds) Aquatic ecosystems: interactivity of dissolved organic matter. Academic Press, San Diego, p 497-498

Smith DC, Azam F (1992) A simple, economical method for measuring bacterial protein synthesis in seawater using ${ }^{3} \mathrm{H}$-leucine. Mar Microb Food Webs 6:107-114

Suzuki MT (1999) Effect of protistan bacterivory on coastal bacterioplankton diversity. Aquat Microb Ecol 20:261-272

van Hannen EJ, Mooij W, van Agterveld MP, Gons HJ, Laanbroek HJ (1999) Detritus-dependent development of the microbial community in an experimental system: Qualitative analysis by denaturing gradient gel electrophoresis. Appl Environ Microbiol 65:2478-2484

Wetzel RG (2001) Limnology: lake and river ecosystems. Academic Press, San Diego

Zarda B, Hahn D, Chatzinotas A, Schonhuber W, Neef A, Amann RI, Zeyer J (1997) Analysis of bacterial community structure in bulk soil by in situ hybridization. Arch Microbiol 168:185-192

Submitted: May 29, 2003; Accepted: December 23, 2003

Proofs received from author(s): May 4, 2004 